\title{
The Effectiveness of Task Based Language Teaching (TBLT) Toward ESP Students' Writing Achievement
}

\author{
Surti Milarisa \\ STIE Muhammadiyah Tanjung Redeb, Berau, East Kalimantan, Indonesia \\ milarisa78@gmail.com
}

\begin{abstract}
TBLT (Task Based Language Teaching) is an approach to language teaching that provides opportunities for students to engage in the authentic use of the target language through tasks. Writing is a process of formulating and organizing ideas in right words, delivering the writer's purpose, and presenting them on a piece of paper. The objective of this research is to know the effectiveness of TBLT (Task Based Language Teaching) toward ESP students' writing achievement at STIE Muhammadiyah Tanjung Redeb. Based on the research result on SPSS 24 calculation, it showed that t-value was 16,678 , while t-table was 2,045 in the $5 \%$ of alpha significance level and 32 degrees of freedom (df). Thus, it indicates that the t-value is higher than t-table $(16,678>1.693$ and can be concluded that there was a significant difference between the two means. In addition, the alternative hypothesis ( $\mathrm{Ha}$ ) of the study was accepted and TBLT (Task Based Language Teaching) was an effective method in teaching writing.
\end{abstract}

Keywords: ESP students, TBLT (Task Based Language Teaching), Writing achievement Citation APA Style: Milarisa, S. (2019). The Effectiveness of Task Based Language Teaching (TBLT) Toward ESP Students' Writing Achievement. English Language in Focus (ELIF), 1(2), 121-126.

\section{INTRODUCTION}

$\mathrm{L}$ anguage is a core element of communications among nations or societies. Since language is used to submit someone's idea and feeling, the world without language like a silent world. As an international language, the ability in English makes the learners easier to master knowledge, mainly in understanding science books written in English.

Furthermore, to provide the students with skills that enable them to communicate in the form of oral and written, writing become one of the objectives in teaching English skill. Writing aims to express ideas, opinions/thoughts, and feelings, that represents a language through the graphic symbol so that understandable to others. Even though writing is an essential ability in mastering English, in fact, it assumed as difficult skill, mainly for EFL learners in tertiary level.

Basically writing skills are activities that tend to be monotonous and 
reluctant for students, especially if they have to do something themselves, without the discussion of partners who can be invited to exchange ideas. Students ideally should be actively involved in every activity in the class. This statement is an ideal situation that should occur in the field of education.

However, the fact on the real field is sometimes still far from ideal. There are still many problems that occur in making harmony between theory and fact. Some students actively participate in learning and others still tend to be passive. Syafini \& Rizan (2010) suggest that extroverted students generally produce more action with less thought while introverted students produce many thoughts with little action. Besides, many researchers have assumed that traditional learning is less effective in meeting student needs. Syafini \& Rizan (2010) suggest that the memorization method has become a common practice in the world of education today in Language Learning.

Based on the problem above, the researcher argues that the teacher needs to provide appropriate tasks for their students so that their writing skills can be improved. In general, there are many techniques that can be applied in teaching writing. Considering facts that are different from the ideal situation, the author feels the need to do a study on how to overcome this problem. The authors, therefore, gave a trial to increase students' active participation and writing skills with TBLT.

According to Ellis (2009), "Tasks Based Language Teaching (TBLT) is related in both fields of second language (L2) pedagogy and L2 acquisition research" (p.4). In this study, therefore, the authors used the implementation of learning media to prove previous studies on the effectiveness of using TBLT in Language Teaching. This strategy is expected to make student learning more active and enjoyable.

\section{RESEARCH METHODOLOGY}

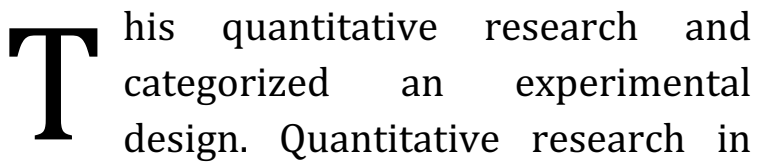
this study which researcher in conducting research using the techniques of test, content analysis and other data collection methods to present the responses and behaviors of the subject. This type of research is often done in the situation scientifically. The experimental type in this research was one group pretest and post-test design, that referred based on Arikunto's theory (2010). The design presented as follow, where $\mathrm{O}_{1}=$ Pre-Test, $\quad \mathrm{O}_{2}=$ Post-Test, and $\mathrm{X}=$ Treatment (Teaching by using TBLT):

Table 1. One Group Pre-test and Post-test Design

\begin{tabular}{lll}
\hline $\mathbf{0}_{1}$ & $\mathrm{X}$ & $\mathbf{0}_{2}$ \\
\hline
\end{tabular}

The variable of this study was referring to research objectives. This research had two variables, as follows: 1) Independent Variable, is a variable that affect or that the cause of the change or the emergence of the dependent variable. The independent variable in this study is Tasks Based Language Teaching (TBLT). 2) Dependent Variable is a variable that is affected or which become a result of the independent variable. The dependent variable in this study is writing narrative text. 
Referring to research design, this research was conducted at STIE Muhammadiyah Tanjung Redeb, accounting class first semester academic year 2017/2018. According to Sugiyono (2013), population is a generalization area consisting of object or subjects that have certain qualities and characteristics are determined by the investigating or to be studied and then drawn conclusions. In brief, it is a set (of collection) of all elements processing one or more attributes of interest.

Table 2. The Population of Research

\begin{tabular}{cc}
\hline Class & Number \\
\hline Accounting A & 36 \\
Accounting B & 32 \\
Accounting C & 33 \\
\hline
\end{tabular}

Source: STIE Muhammadiyah Tanjung Redeb

While the sample of this study was accounting $C$ that consisted of 33 students, including 15 female and 18 male students. The writer chooses this class because the writer looks that the average of students' value in the writing category is low. According to Sugiyono (2013), sample is part of the number and characteristics possessed by the population. The writer used purposive sampling technique because the member of the population was purposively selected and considered in the same ranging of three classes, 101 students.

Instrument of the research is a facility which is used by the researcher in collecting the data. It has purpose to make work become easier and the product becomes better. It means quicker, complete and systematic. The instrument therefore of this study is test. According to Arikunto (2010), test is a set of question or practice and the other instrument which is used for the researcher collected, arranged and presented data.

In the study, the pre-test was conducted in order to know the students 'prior achievement in writing descriptive text. Moreover, it was given to identify students 'weaknesses in writing. The researcher was given pre-test for students on the $10^{\text {th }}$ September 2018 from 12.30 p.m. to 02.00 p.m. Before the research was conducted. The students were asked to produce a narrative text after given a short explanation and sample about narrative text. The results of the students'writing were analyzed based on the table of scoring the writing test. The time allotment given was 90 minutes. The result will be classified by using the following criteria:

Table 3. Classification of students' score

\begin{tabular}{ccc}
\hline No & Score & Classification \\
\hline 1. & $<85-100$ & Excellent \\
2. & $<70-84$ & Good \\
3. & $<60-69$ & Satisfactory \\
4. & $<50-59$ & Poor \\
5. & $<49-0$ & Weak \\
\hline
\end{tabular}

The result of this pre-test would be compared with the result of the posttest or after students given treatments. The aim of this comparison was to determine the score of students 'writing skill of narrative text.

\section{FINDING AND DISCUSSION}

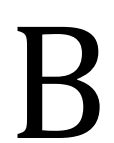
ased on the result of the test, the pre-test can be classified as follows: 0 students can be classified excellent, 2 students can be classified good, 11 students can be classified satisfactory, 18 students can be classified poor and 2 students can be classified weak. While the post-test data 
can be classified as follows: 9 students can be classified excellent, 24 students can be classified good, 0 students can be classified satisfactory, 0 students can be classified poor, and, 0 students can be classified weak. The mean score from 33 students was 81,3 , that can be classified good.

In this research, the writer conducted the treatment of the research sample. The writer conducted two meeting that focused on teaching writing on narrative text by using TBLT. In the treatment, the writer explained about narrative task-based and how to apply TBLT. Then the writer divided students into small group discussion. With step by step and detail explanation from the writer, they started to understand TBLT procedures. After the treatment, the writer conducted the post-test. It was used to identify the students' ability after treatment. Then, the writer calculated the mean score of post-test by dividing the total score of post-test with the whole number of research sample that is 33 students. The mean score of post-test was 81,3 . It showed that students' mean score had improved from pre-test to post-test, 57,8 to 81,3 .

Then the total of average (Mean) gained score that having been achieved by the students of accounting class at STIE Muhammadiyah Tanjung Redeb in was 2.440, was obtained from the SPSS calculation. In conclusion, the students who were interested in writing had been good learning achievements. Then the writer analyzed the significant of students' interval score of pre-test and post-test using t-test formula. Based on computation, the result showed that the t-test score 16,789 was higher than $t$ table 1.693 at 0,05 with the degree of freedom (df) $=\mathrm{N}-1$ (33-1). It means that the use of TBLT in teaching. writing narrative text had difference significant result between pre-test and post-test.

In sum, it was clear that there was significance effect of the accounting students who were taught by TBLT teaching writing on personal narrative text. It can be seen by the mean score of pre-test that was 57,8 and became 81,3 at the post-test at the STIE Muhammadiyah Tanjung Redeb. Next, the result of the treatment which had counted by using t-test was 16,678 . Then she consults the critical value on the $t$ table using the 5\% alpha level of significance and 32 degrees of freedom (df) is1.693. Since the obtaining $t_{\text {value }}$ is 16,678 and the $t_{\text {table }}$ is 1.693 which means that the $t_{\text {value }}$ is higher than $t_{\text {table }}$ $(16,678>1.693)$, there is significant difference between the two means.

From the data analysis, the students' ability in narrative text there is an effect of TBLT in teaching writing narrative text. The strategy was helpful for the writer in making students' understanding of writing personal narrative text became clear. In some cases, the increase in student's writing personal narrative text would also be determined by a learning situation and the strategy used to teach them, it should be appropriate with the level of the students. For example, the description about personal narrative text by using TBLT had been actually proved in this study that it was completely able to create such a learning situation which was not going to take the students into serious. 


\section{CONCLUSION}

B

ased on research findings that were carried out in STIE Muhammadiyah Tanjung Redeb, the writer concluded that there is an effect of TBLT in teaching writing narrative text. The result of observation shown how the use of TBLT. It can be proven by the result average pre-test and post-test. Where 57,8 for pre-test and 81,3 for post-test. The average post-test is higher than pre-test. The writer calculates the difference of the two means, it was proven by the comparison between the result of the pre-test and post-test in which the post test result was higher $(20.1 \%)$ than pre-test $(14.3 \%)$. So the increase is $(5.8 \%)$.

As the mean of the post-test was statistically higher than that of the pretest. The result of the test shows that most students have positive responses and interest toward the usage of TBLT in teaching writing. Since the obtaining $t_{\text {value }}$ is 16,678 and the $t_{\text {table }}$ is 1.693 which means that the $t_{v a l u e}$ is higher than $t_{\text {table }}$ $(16,678>1.693)$, there is significant difference between the two means. It can prove TBLT was helpful for the students that they could increase their writing skill of the text passage. It can motivate and encourage them to understanding when they writing and active in conducting lesson. It means that the using of TBLT helped students learn and made them easy to understand the content of the text in learning English especially writing personal narrative text.

\section{REFERENCES}

Arikunto, S. (2010). Prosedur Penelitian Suatu Pendekatan Praktik. Jakarta: Rineka Cipta.

Ellis, R. (2009). Task-Based Language Teaching: Sorting Out the Misunderstandings. International Journal of Applied Linguistics, 19(3), 221-246. https://doi.org/10.1111/j.14734192.2009.00231.x

Sugiyono. (2013). Metode Penelitian Kuantitatif, Kualitatif, dan $R \& D$. Bandung: Alfabeta.

Syafini, \& Rizan, T. N. (2010). The Effects of Cooperative Learning in Enhancing Writing Performance. Retrieved from http://www.ukm.my/solls09/Proc eeding/PD\%0AF/ Shafini.pdf 
English Language in Focus (ELIF), 1 (2), 121-126. https://jurnal.umj.ac.id/index.php/ELIF 